\title{
RESEARCH ON LUBRICATION PROPERTIES OF SELECTED RAW PLANT AND ANIMAL MATERIALS
}

\author{
Leszek GARDYŃSKI*, Jolanta KAŁDONEK \\ Dept of Materials Science and Engineering, Faculty of Mechanical Engineering, \\ Lublin University of Technology, Poland
}

Received 11 May 2016; revised 8 February 2017; accepted date 12 March 2017

\begin{abstract}
The article presents the results of research on lubrication properties of rapeseed oil, methyl esters of rapeseed oil, as well as esters with goose fat. Rapeseed oil has a better lubrication properties in relation to methyl esters of rapeseed oil. Addition of goose fat to esters negatively affected their lubrication properties. The presented results confirm a relationship between the degree of unsaturated and lubricated properties. Among the tested compounds with oxygen groups $(\mathrm{COOH}$, $\mathrm{COOCH}_{3}, \mathrm{C}=\mathrm{O}$ ), the oleic acid (with a COOH group) characterised the best lubricity. The fat goose, which contains the least amount of unsaturated fatty acid esters, proved to be ineffective addition lubricity between the factor lubricants analysis.
\end{abstract}

Keywords: biodiesel, rapeseed oil, methyl esters of the fatty acids of rapeseed oil, lubricity, wear testing.

\section{Notations}

C - carbon;

C16:0 - 16 carbon atoms and 0 double bond between carbon atoms;

C18:0 - 18 carbon atoms and 0 double bond between carbon atoms;

C18:1 - 18 carbon atoms and 1 double bond between carbon atoms;

C18:2 - 18 carbon atoms and 2 double bond between carbon atoms;

C18:3 - 18 carbon atoms and 3 double bond between carbon atoms;

$\mathrm{COOH}$ - carboxyl group;

DMC - dimethyl carbonate;

$\mathrm{H}$ - hydrogen;

HFRR - high frequency reciprocating rig;

$\mathrm{KOH}$ - potassium hydroxide (caustic potash);

$\mathrm{O}$ - oxygen;

$\mathrm{OH}$ - hydroxyl group;

RME - rapeseed oil methyl esters.

\section{Introduction}

The availability of adequate amount of conventional fossil fuel for internal combustion engines and the associated effects of global warming and other environmental issues arising due to the combustion of fossil fuels are the two most threatening problems of our present civilization (Datta, Mandal 2016). The fossil fuels are finite resources and their mass consumption has significant impacts on our environment and society (Sugami et al. 2016). Automotive sector has a big impact on the natural environment (Marczuk et al. 2015). Energy intensity of the vehicle can be determined on the basis of a driving simulation based on driving cycles for fuel consumption and harmful emissions measuring (Barta, Mruzek 2014). A growing awareness of the impoverishment of the fossil fuels has lead to an intensive search for renewable fuels (Gustavsson et al. 2012). Scientists from different corners of the world are making sincere attempts to find out the suitable alternative fuels (Datta, Mandal 2016; Sugami et al. 2016; Kobus et al. 2015; Mickevičius et al. 2014; Myczko, Golimowska 2011; Szlachta 2002; Nazimek et al. 2015) and can be found many researches of engine operational conditions (Barta, Mruzek 2014; Figlus, Liščák 2014; Droździel, Krzywonos 2009; Macián et al. 2016; Mikulski et al. 2016; Panneer Selvam, Vadivel 2012; Lin, Li 2009) and diagnostics (Figlus 2015; Głowacz 2010, 2015; Jedliński et al. 2015; Armas et al. 2013).

The article presents the results of the tests of rapeseed oil lubricity, RME and RME with addition of goose fat.

${ }^{*}$ Corresponding author. E-mail: l.gardynski@pollub.pl 


\section{Biofuels for diesel engines}

Selection of raw material for the production of biofuels depends mainly on the geographical region. This can be edible and nonedible vegetable oils, produced from rapeseed, soybean, sunflower seed, rice bran, tobacco, cotton, as well as animal fats and waste fats (Myczko, Golimowska 2011). The first place in the world in production takes soybean oil, obtained in moderate climate and palm oil, obtained in hot climate. In Poland, the main raw material for the production of biofuels is rapeseed oil (Szlachta 2002).

Using inedible material and fat material considered to be waste raises no controversy on unethical applications of food sources, but makes it possible to, at least partially, satisfy the demand for renewable energy, thus enabling environmentally friendly disposal of material that is considered to be a waste product (Macián et al. 2016). Most authors (Sugami et al. 2016; Kobus et al. 2015; Mickevičius et al. 2014; Szlachta 2002; Zdziennicka et al. 2015), focus on the use of biofuels of plant origin. Studies on the use of fuels of animal origin are significantly less frequent (Mikulski et al. 2016; Panneer Selvam, Vadivel 2012; Lin, Li 2009; Armas et al. 2013; Sakthivel et al. 2014; Barrios et al. 2014; Öner, Altun 2009; Behçet 2011).

Poland is, along with Hungary, in the leading position in breeding goose in Europe. About 24 thousand tons of goose meat is produced per year, of which approximately $93 \%$ is exported. $100 \mathrm{~g}$ of goose meat contains $32 \mathrm{~g}$ of fat, i.e. per year in Poland is produced about 7680 tons of goose fat (Szczepańska-Piszcz 2010). Poultry fat is a production waste in meat industry. This is a low-cost raw material, usually not used in food and non-food products (Kostecka 2008).

Of the biodiesel, vegetable oils canola oil is especially frequently used (Zdziennicka et al. 2015). Vegetable oils and animal fats are composed primarily of triglycerides, which by the chemical nature are esters of fatty acids and glycerol. One glycerol molecule is connected with three, most often different ones, chains of the fatty acids (Myczko, Golimowska 2011), containing from 14 to 24 carbon atoms. Between carbon atoms is a different number of double bonds, focusing on the extent saturated fatty acids. The greater the number of double bonds in fatty acid, the greater the insatiability of acid. In a natural rapeseed oil is about $95 . . .98 \%$ of the triglycerides, which are dominated by esters of unsaturated: oleic, linoleic and linolenic acids (Szlachta 2002). Goose fat contains little amount of saturated acids compared to mammals fat (Kostecka, Kowalski 2011) and so much more as compared to vegetable oils.

In the vegetable oils and animal fats are included, as well as, among other things, free fatty acids, i.e. unbound acids in glycerol esters (Szlachta 2002). They result from oxidation of carbon chains, which contributes the occurrence of double bonds, e.g. during heating (Myczko, Golimowska 2011). Quantity of free fatty acids is referred by the acid number. This is the amount of $\mathrm{mg} \mathrm{KOH}$ required to neutralize fatty acids present in 1 gram of the given factor (Gil, Ignaciuk 2011).
During the rapeseed oil transesterification occurs rebuilding of triglycerides, i.e. molecules of methanol (ethanol or butanol) create along with fatty acid residue molecules fatty acid methyl esters molecules of rapeseed oil, and glycerol (Szlachta 2002). However, free fatty acids react with alkalis, and the resulting soap and water are removed during purification of esters (Myczko, Golimowska 2011).

An alternative for methanol in transesterification process is DMC, which may solve the problem of the large amount of glycerol resulting in this process (Sun et al. 2014).

Triglycerides of vegetable oils and animal fats contain functional group $\mathrm{C}=\mathrm{O}$. At the end of the hydrocarbon chain of the free fatty acid there is $\mathrm{COOH}$, while in methyl esters of rapeseed oil is $\mathrm{COOCH}_{3}$.

In research by Knothe and Steidley (2005) is described lubricity test, carried out with the friction apparatus HFRR and using oxygenates, containing 10 carbon atoms. The following order of oxygen groups was received, increasing lubrication properties: $\mathrm{COOH}>\mathrm{CHO}>\mathrm{OH}>\mathrm{COOCH}_{3}>$ $\mathrm{C}=\mathrm{O}>\mathrm{C}-\mathrm{O}-\mathrm{C}$. Fuel with a low lubricity with the addition of free fatty acids has been also examined, receiving a significant improvement of lubricity, which is confirmed by previous studies (Kajdas, Majzner 2001a, 2001b; Kenesey, Ecker 2003). Biodiesel from castor oil increases the lubricity due to the presence of contaminants as free fatty acids or glycerol, which have been observed to behave as lubricity imparting moieties (Agarwal et al. 2013; Knothe 2005; Cvengroš et al. 2006; Meneghetti et al. 2006a, 2006b; Scholz, Da Silva 2008; Canoira et al. 2010).

Initial correlation between the degree of unsaturation and lubricity was presented by Geller and Goodrum (2004). Examined fatty acid methyl esters, ester of stearic acid (C18:0), ester of oleic acid (C18:1), ester of linoleic acid (C18:2) and linolenic acid ester (C18:3) show improvement of lubricity, together with the increase of unsaturation, i.e. the number of double bonds between carbon atoms. Therefore, among the tested esters, the ester of stearic acid in the smallest extent affected such properties, meanwhile the ester of linolenic acid effectively improved lubricity.

Liquid film occurs very often in industrial applications with thicknesses that may range from below $10 \mu \mathrm{m}$ to above $5 \mathrm{~mm}$ (Cui et al. 2014). Engine tribology has been always an important subject of study in the automotive industry (Macián et al. 2016). Some tribological components in automotive engines operate in direct contact with the fuel, under severe conditions (Gustavsson et al. 2012). This includes fuel system, injection pumps and plungers.

\section{Materials and methods}

The tests have been carried out on the test bench, as described in detail in the research by Gardyński (2005) and shown in Figure 1.

They based on simultaneous abrading of three samples in the form of cone bearing rollers (diameter $\varnothing=5 \mathrm{~mm}$ ) on a rotating flat counter sample in form of a longitudinal bearing race, in conditions of lubrication by lubrication 


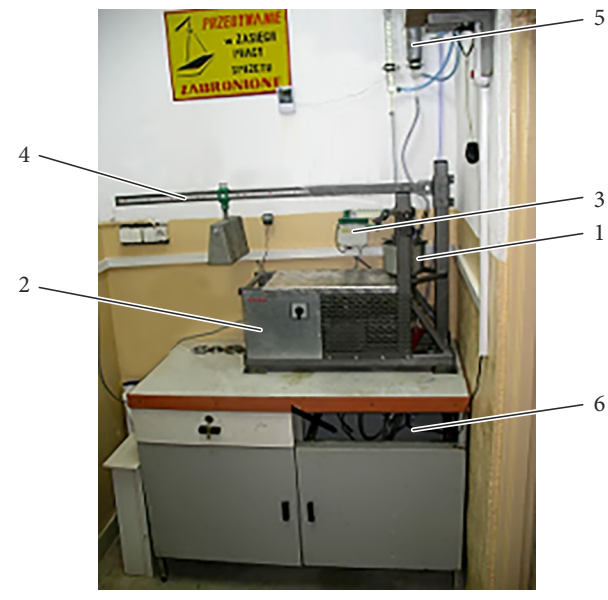

Figure 1 . The test bench to determine lubrication and resistance of materials to wear: 1 - the shield of friction node; 2 - the base and the drive of friction machine; 3 - measuring system of the friction moment; 4 - weighing arm; 5 - temperature stabilization system of the tested lubricant; 6 - circulation system and lubricant filtration (Gardyński 2005)

factor at temperature of $333 \mathrm{~K}$, pressure of $29.43 \mathrm{kN}$ and total path of friction approximately $2 \times 104 \mathrm{~m}$. The lubricating agent, in quantities of $30 \mathrm{dm}^{3}$ circulated in the closed circuit and was filtered, and temperature stabilized. The lubricity was evaluated by loss of mass and surface of samples and by the coefficient of friction.

Rapeseed oil, RME and RME with goose fat were tested. The share of fatty acids in selected vegetable oils and goose fat is shown in Table 1, the acid numbers are shown in Table 2.

\section{Results and discussion}

Figure 2 shows macroscopic images of footprint area of cooperation of friction samples while lubricating by use of rapeseed oil, RME and RME with goose fat.

The smallest footprint area of cooperation was observed for samples lubricated with rapeseed oil. For samples lubricated with RME was found out larger footprint area of cooperation, while the footprint area of cooperation of samples after conducted lubrication with RME with goose fat is the largest, which is confirmed by quantitative
Table 2. Acid number of the tested materials (Wroniak et al. 2006)

\begin{tabular}{|l|c|}
\hline \multicolumn{1}{|c|}{ The name of oil } & Acid number $[\mathrm{mg} \mathrm{KOH} / \mathrm{g}]$ \\
\hline Rapeseed oil & 1.65 \\
\hline Soybean oil & 2.24 \\
\hline Sunflower oil & 2.35 \\
\hline Corn oil & 4.93 \\
\hline Peanut oil & 1.35 \\
\hline Rice oil & 1.2 \\
\hline RME $^{* *}$ & 0.38 \\
\hline Oleic acid & 198.69 \\
\hline Goose fat & 0.86 \\
\hline
\end{tabular}

Sources: ${ }^{*}$ Wikipedia (2016); ${ }^{* *}$ Gardyński (2013); ${ }^{* *}$ Gil and Ignaciuk (2011); ${ }^{* * * *}$ Pomianowski and Dajnowiec (2009).

results of lubricity factors of tested agents presented in Figure 3, as well as described in research by Gardyński and Kałdonek (2013).

Quantitative results of research RME and RME with goose fat are in Figure 3.

Addition of goose fat to methyl esters of rapeseed oil has resulted in an increase in mass loss of samples and the footprint area of cooperation and its equivalent diameter, when using this lubricant.

The previous studies described in research by Gardyński and Kałdonek (2013), indicate that the best lubrication properties of tested vegetable oils had soybean oil, i.e. oil containing the largest number of unsaturated acid esters, which is in line with earlier dependence.

As far as the tests outlined in research by Kiernicki et al. (2007), the addition of oleic acid $-\mathrm{CH}_{3}\left(\mathrm{CH}_{2}\right)_{7} \mathrm{CH}=$ $\mathrm{CH}\left(\mathrm{CH}_{2}\right)_{7} \mathrm{COOH}$, i.e. acid containing one double bond between carbon atoms and the $\mathrm{COOH}$ to methyl esters of rapeseed oil contributes positively to their lubrication properties.

Acid number of vegetable oil is higher than the acid number of methyl esters of rapeseed oil. According to sequence of oxygen groups, the $\mathrm{COOH}$ strongly affects the lubrication properties. For the lubrication properties of the methyl esters is mainly responsible group $\mathrm{COOCH}_{3}$, while group $\mathrm{C}=\mathrm{O}$, i.e. triglycerides group of vegetable oils and animal fats occurs in further place of the listed sequence.

Table 1. The content of the fatty acids in vegetable oils (Baczewski, Kałdoński 2008) and goose fat [\% of mass]

\begin{tabular}{|l|c|c|c|c|c|}
\hline \multicolumn{1}{|c|}{ The name of oil } & $\begin{array}{c}\text { C18:1 } \\
\text { oleic acid }\end{array}$ & $\begin{array}{c}\text { C18:2 } \\
\text { linoleic acid }\end{array}$ & $\begin{array}{c}\text { C18:3 } \\
\text { linolenic acid }\end{array}$ & $\begin{array}{c}\text { C16:0 } \\
\text { palmitic acid }\end{array}$ & $\begin{array}{c}\text { C18:0 } \\
\text { stearic acid }\end{array}$ \\
\hline Rapeseed oil & $60 \ldots 73$ & $19 \ldots 22$ & $9 \ldots 10$ & $2 \ldots 4.8$ & $1.2 \ldots 2$ \\
\hline Soybean oil & $22 \ldots 34$ & $53 \ldots 60$ & $2 \ldots 10,8^{* * *}$ & $7 \ldots 11$ & $2.1 \ldots 6$ \\
\hline Sunflower oil & $17 \ldots 18,22^{* * *}$ & $71 \ldots 74,66^{* * *}$ & 0.5 & $6 \ldots 7$ & $11 \ldots 12$ \\
\hline Corn oil & $30 \ldots 50,28^{* *}$ & $34 \ldots 56,58^{* * *}$ & 1.0 & $11 \ldots 11.4$ & $2 \ldots 2.4$ \\
\hline Peanut oil & $48 \ldots 48.5$ & $32 \ldots 34$ & $0.9 \ldots 1.0$ & 5 & 1.9 \\
\hline Rice oil $^{*}$ & 42.5 & 39.1 & 1.1 & 23.3 & 8 \\
\hline Goose fat $^{* *}$ & 52.9 & 11.2 & 0.54 & & 8 \\
\hline
\end{tabular}

Sources: ${ }^{*}$ Śliwki robaczywki (2013); ${ }^{* *}$ Pomianowski and Dajnowiec (2009); ${ }^{* *}$ Szlachta (2002). 
a)

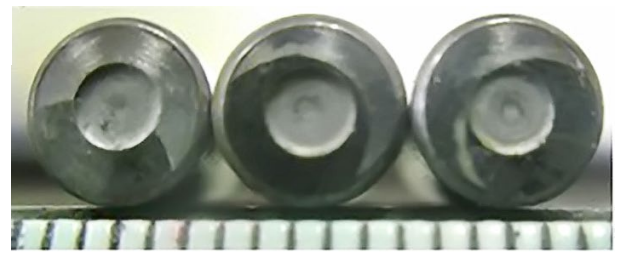

b)

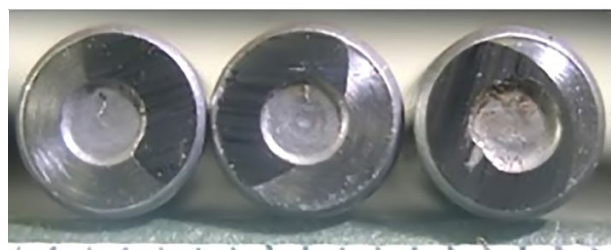

11111111111114

c)

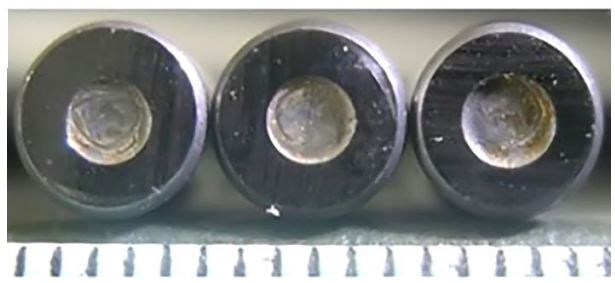

Figure 2. The image of friction samples in lubrication conditions: a - using rapeseed oil; b - RME; c - RME with goose fat (dark area represents a track of cooperation)

Addition of goose fat to methyl esters of rapeseed oil, i.e. fat containing more than $30 \%$ of saturated esters, and therefore less unsaturated acid esters in relation to vegetable oils, affected negatively the lubrication properties of esters. Despite the higher number of goose fat than acid number of methyl esters of rapeseed oil, the increased consumption of samples lubricated with fuel containing this additive was observed. The content of esters of saturated acids in goose fat and the presence of $\mathrm{C}=\mathrm{O}$ responsible for lubricity had a decisive influence on the results of the tests.

\section{Conclusions}

Based on the results of tests carried out the following conclusions were drawn:

- the obtained results of the studies are in accordance with the presented, reported in the literature sequence of oxygen groups improving lubricity;

- the content of esters of saturated acids negatively affects the lubrication properties of goose fat, which reduces the possibility of implementation of this post-production waste in test form in biofuels;

- further attempts to use goose fat as a component of a biofuels should be carried out on the processed material with an increased participation of unsaturated fatty acids in relation to saturated ones.

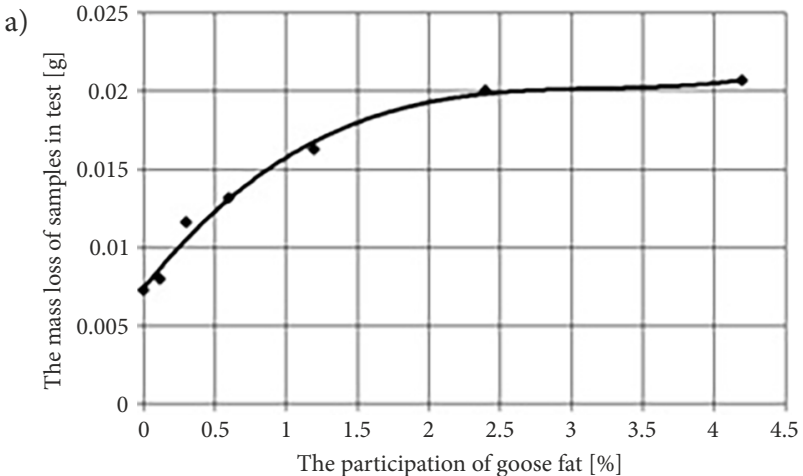

b)

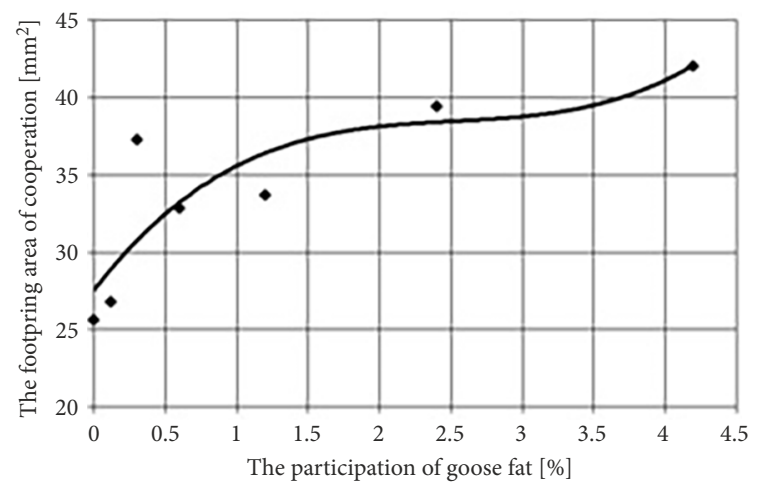

c)

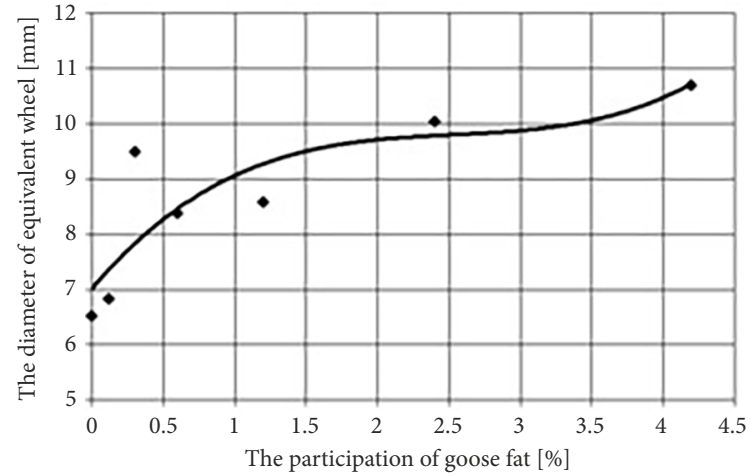

d)

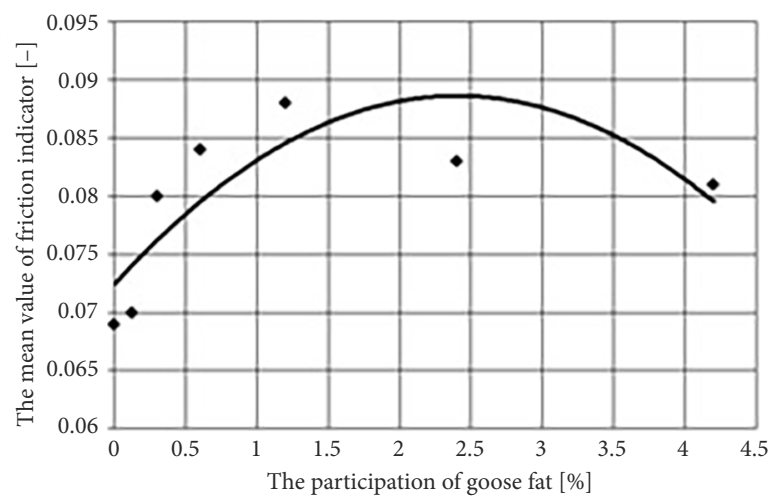

Figure 3. The results of the lubricants features of RME with goose fat: a - mass loss of samples; $\mathrm{b}$ - the footprint area of cooperation; $\mathrm{c}$ - the diameter of an equivalent wheel; $\mathrm{d}-$ the average value of coefficient of friction 


\section{Contribution}

Leszek Gardyński was responsible for the concept of the article and study, supervised all stages of the study, participated in possession of the materials, collection and interpretation of data, and writing the manuscript.

Jolanta Kałdonek provided the test bench and interpretation of data, supervised all stages of the study and writing the manuscript.

Both authors have read and approved the manuscript.

\section{Disclosure statement}

We are reporting that this research is not sponsored by any company and they not have any competing financial, professional, or personal interests from other parties.

\section{References}

Agarwal, S.; Chhibber, V. K.; Bhatnagar, A. K. 2013. Tribological behavior of diesel fuels and the effect of anti-wear additives, Fuel 106: 21-29. https://doi.org/10.1016/j.fuel.2012.10.060

Armas, O.; Gómez, A.; Ramos, Á. 2013. Comparative study of pollutant emissions from engine starting with animal fat biodiesel and GTL fuels, Fuel 113: 560-570. https://doi.org/10.1016/j.fuel.2013.06.010

Baczewski, K.; Kałdoński, T. 2008. Paliwa do silników o zapłonie samoczynnym. Wydawnictwa komunikacji i łączności. $224 \mathrm{~s}$. (in Polish).

Barrios, C. C.; Domínguez-Sáez, A.; Martín, C.; Álvarez, P. 2014. Effects of animal fat based biodiesel on a TDI diesel engine performance, combustion characteristics and particle number and size distribution emissions, Fuel 117: 618-623. https://doi.org/10.1016/j.fuel.2013.09.037

Barta, D.; Mruzek, M. 2014. Non-conventional drive and its possibilities of using in road vehicles of public transport, in $O P T$ i 2014 - 1st International Conference on Engineering and Applied Sciences Optimization: Proceedings, 4-6 June 2014, Kos Island, Greece, 2049-2061.

Behçet, R. 2011. Performance and emission study of waste anchovy fish biodiesel in a diesel engine, Fuel Processing Technology 92(6): 1187-1194.

https://doi.org/10.1016/j.fuproc.2011.01.012

Canoira, L.; García Galeán, J.; Alcántara, R.; Lapuerta, M.; García-Contreras, R. 2010. Fatty acid methyl esters (FAMEs) from castor oil: production process assessment and synergistic effects in its properties, Renewable Energy 35(1): 208-217. https://doi.org/10.1016/j.renene.2009.05.006

Cui, Z.; Yang, C.; Sun, B.; Wang, H. 2014. Liquid film thickness estimation using electrical capacitance tomography, Measurement Science Review 14(1): 8-15. https://doi.org/10.2478/msr-2014-0002

Cvengroš, J.; Paligová, J.; Cvengrošová, Z. 2006. Properties of alkyl esters base on castor oil, European Journal of Lipid Science and Technology 108(8): 629-635.

https://doi.org/10.1002/ejlt.200600031

Datta, A.; Mandal, B. K. 2016. A comprehensive review of biodiesel as an alternative fuel for compression ignition engine, $R e$ newable and Sustainable Energy Reviews 57: 799-821. https://doi.org/10.1016/j.rser.2015.12.170

Droździel, P.; Krzywonos, L. 2009. The estimation of the reliability of the first daily diesel engine start-up during its operation in the vehicle, Eksploatacja i Niezawodność - Maintenance and Reliability (1): 4-10.
Figlus, T. 2015. The application of a continuous wavelet transform for diagnosing damage to the timing chain tensioner in a motorcycle engine, Journal of Vibroengineering 17(3): 1286-1294.

Figlus, T.; Liščák, S. 2014. Assessment of the vibroactivity level of SI engines in stationary and non-stationary operating conditions, Journal of Vibroengineering 16(3): 1349-1359.

Gardyński, L. 2005. Stanowisko do badania odporności materiału elementów aparatury paliwowej na zużycie w warunkach smarowania, VII Sympozjum Naukowo-techniczne "Silniki spalinowe $w$ zastosowaniach wojskowych" - SILWOJ 2005, 26-28 października 2005, Rynia, Polska, 93-100. (in Polish).

Gardyński, L. 2013. Wyniki badań własności smarnych wybranych biopaliw, Combustion Engines (3): 1109-1114. (in Polish).

Gardyński, L.; Kałdonek, J. 2013. Comparative study of selected lubricating properties of biofuels, Advances in Science and Technology Research Journal 7(20): 75-79.

Geller, D. P.; Goodrum, J. W. 2004. Effects of specific fatty acid methyl esters on diesel fuel lubricity, Fuel 83(17-18): 23512356. https://doi.org/10.1016/j.fuel.2004.06.004

Gil, L.; Ignaciuk, P. 2011. Wpływ liczby kwasowej na smarność biopaliw, Postępy nauki i techniki (11): 37-42. (in Polish).

Głowacz, A. 2010. Diagnostyka maszyny prądu stałego oparta na rozpoznawaniu dźwięku z zastosowaniem LPC i GSDM, Przegląd Elektrotechniczny 86(6): 243-246. (in Polish).

Głowacz, A. 2015. Recognition of acoustic signals of synchronous motors with the use of MoFS and selected classifiers, Measurement Science Review 15(4): 167-175.

https://doi.org/10.1515/msr-2015-0024

Gustavsson, F.; Forsberg, P.; Jacobson, S. 2012. Friction and wear behaviour of low-friction coatings in conventional and alternative fuels, Tribology International 48: 22-28. https://doi.org/10.1016/j.triboint.2011.06.001

Jedliński, Ł.; Caban, J.; Krzywonos, L.; Wierzbicki, S.; Brumerčík, F. 2015. Application of vibration signal in the diagnosis of IC engine valve clearance, Journal of Vibroengineering 17(1): 175-187.

Kajdas, C.; Majzner, M. 2001a. Boundary lubrication of low-sulphur diesel fuel in the presence of fatty acids, Lubrication Science 14(1): 83-108. https://doi.org/10.1002/ls.3010140107

Kajdas, C.; Majzner, M. 2001b. The influence of fatty acids and fatty acids mixtures on the lubricity of low-sulfur diesel fuels, SAE Technical Paper 2001-01-1929.

https://doi.org/10.4271/2001-01-1929

Kenesey, E.; Ecker, A. 2003. Sauerstoffverbindungen zur Verbesserung der Lubricity in Kraftstoffen, Tribologie und Schmierungstechnik 50(2): 21-26. (in German).

Kiernicki, Z.; Gardyński, L.; Sawa, J.; Hys, L. 2007. The effect of biofuel acid number on some operational and wear properties of DI diesel, in Fuels 2007: 6th International Colloquium on Fuels, 10-11 January 2007, Ostfildern, Esslingen District, Germany, 641-647.

Knothe, G. 2005. Dependence of biodiesel fuel properties on the structure of fatty acid alkyl esters, Fuel Processing Technology 86(10): 1059-1070.

https://doi.org/10.1016/j.fuproc.2004.11.002

Knothe, G.; Steidley, K. R. 2005. Lubricity of components of biodiesel and petrodiesel. The origin of biodiesel lubricity, Energy \& Fuels 19(3): 1192-1200. https://doi.org/10.1021/ef049684c

Kobus, Z.; Mazur, J.; Nadulski, R.; Guz, T.; Rydzak, L.; Zawiślak, K. 2015. Modification of rheological properties of vegetable oils, Przemysł chemiczny 94(10): 1728-1731. 
Kostecka, M. 2008. Charakterystyka mieszaniny tłuszczu drobiowego $\mathrm{z}$ olejem rzepakowym przed i po przeestryfikowaniu enzymatycznym, ŻYWNOŚĆ: nauka - technologia - jakość 5(60): 257-272.

Kostecka, M.; Kowalski, B. 2011. Charakterystyka mieszaniny tłuszczu gęsiego $\mathrm{z}$ olejem rzepakowym $(2: 3 \mathrm{M} / \mathrm{M})$ przed i po przeestryfikowaniu w obecności preparatu lipozyme, Bromatologia i chemia toksykologiczna 44(2): 194-198. (in Polish).

Lin, C.-Y.; Li, R.-J. 2009. Engine performance and emission characteristics of marine fish-oil biodiesel produced from the discarded parts of marine fish, Fuel Processing Technology 90(7-8): 883-888. https://doi.org/10.1016/j.fuproc.2009.04.009

Macián, V.; Tormos, B.; Ruiz, S.; Miró, G. 2016. Low viscosity engine oils: Study of wear effects and oil key parameters in a heavy duty engine fleet test, Tribology International 94: 240-248. https://doi.org/10.1016/j.triboint.2015.08.028

Marczuk, A.; Misztal, W.; Słowik, T.; Piekarski, W.; Bojanowska, M.; Jackowska, I. 2015. Chemical determinants of the use of recycled vehicle components, Przemyst chemiczny 94(10): 1867-1871. https://doi.org/10.15199/62.2015.10.46

Meneghetti, S. M. P.; Meneghetti, M. R.; Wolf, C. R.; Silva, E. C.; Lima, G. E. S.; Coimbra, M. A.; Soletti, J. I.; Carvalho, S. H. V. 2006a. Ethanolysis of castor and cottonseed oil: A systematic study using classical catalysts, Journal of the American Oil Chemists' Society 83(9): 819-822. https://doi.org/10.1007/s11746-006-5020-3

Meneghetti, S. M. P.; Meneghetti, M. R.; Wolf, C. R.; Silva, E. C.; Lima, G. E. S.; Silva, L. L.; Serra, T. M.; Cauduro, F.; De Oliviera, L. G. 2006b. Biodiesel from castor oil: a comparison of ethanolysis versus methanolysis, Energy \& Fuels 20(5): 2262-2265. https://doi.org/10.1021/ef060118m

Mickevičius, T.; Slavinskas, S.; Wierzbicki, S.; Duda, K. 2014. The effect of diesel-biodiesel blends on the performance and exhaust emissions of a direct injection off-road diesel engine, Transport 29(4): 440-448.

https://doi.org/10.3846/16484142.2014.984331

Mikulski, M.; Duda, K.; Wierzbicki, S. 2016. Performance and emissions of a CRDI diesel engine fuelled with swine lard methyl esters-diesel mixture, Fuel 164: 206-219.

https://doi.org/10.1016/j.fuel.2015.09.083

Myczko, A.; Golimowska, R. 2011. Porównanie właściwości estrów metylowych w zależności od pochodzenia surowca, Journal of Research and Applications in Agricultural Engineering 56(2): 111-117. (in Polish).

Nazimek, D.; Słowik, T.; Zając, G.; Krzaczek, P.; Kuranc, A.; Szyszlak-Bargłowicz, J.; Piekarski, W.; Marczuk, A. 2015. Studies on physicochemical properties of catalyst precursors for the preparation DME from ethanol, Przemyst chemiczny 94(10): 1772-1777. https://doi.org/10.15199/62.2015.10.24

Öner, C.; Altun, Ş. 2009. Biodiesel production from inedible animal tallow and an experimental investigation of its use as alternative fuel in a direct injection diesel engine, Applied Energy 86(10): 2114-2120.

https://doi.org/10.1016/j.apenergy.2009.01.005

Panneer Selvam, J. D.; Vadivel, K. 2012. Performance and emission analysis of DI diesel engine fuelled with methyl esters of beef tallow and diesel blends, Procedia Engineering 38: 342-358. https://doi.org/10.1016/j.proeng.2012.06.043

Pomianowski, J. F.; Dajnowiec, F. 2009. Właściwości fizykochemiczne tłuszczu gęsiego, Inżynieria i aparatura chemiczna 48(1): 58-59. (in Polish).
Sakthivel, G.; Nagarajan, G.; Ilangkumaran, M.; Gaikwad, A. B. 2014. Comparative analysis of performance, emission and combustion parameters of diesel engine fuelled with ethyl ester of fish oil and its diesel blends, Fuel 132: 116-124. https://doi.org/10.1016/j.fuel.2014.04.059

Scholz, V.; Da Silva, J. N. 2008. Prospects and risks of the use of castor oil as a fuel, Biomass and Bioenergy 32(2): 95-100. https://doi.org/10.1016/j.biombioe.2007.08.004

Sugami, Y.; Minami, E.; Saka, S. 2016. Renewable diesel production from rapeseed oil with hydrothermal hydrogenation and subsequent decarboxylation, Fuel 166: 376-381.

https://doi.org/10.1016/j.fuel.2015.10.117

Sun, S.; Zhang, L.; Meng, X.; Ma, C.; Xin, Z. 2014. Biodiesel production by transesterification of corn oil with dimethyl carbonate under heterogeneous base catalysis conditions using potassium hydroxide, Chemistry and Technology of Fuels and Oils 50(2): 99-107. https://doi.org/10.1007/s10553-014-0495-3

Szczepańska-Piszcz, M. 2010. Gąska modna, Tygodnik "Przegląd", 12 grudnia 2010. Available from Internet: https://www.tygodnikprzeglad.pl/gaska-modna (in Polish).

Szlachta, Z. 2002. Zasilanie silników wysokoprężnych paliwami rzepakowymi. Wydawnictwa komunikacji i łączności. $218 \mathrm{~s}$. (in Polish).

Śliwki robaczywki. 2013. Olej ryżowy - wprowadzenie. Available from Internet: http://www.sliwkirobaczywki.com/2013/04/ olej-ryzowy-wprowadzenie.html (in Polish).

Wikipedia. 2016. Rice Bran Oil. Available from Internet: https://en.wikipedia.org/wiki/Rice_bran_oil

Wroniak, M.; Kwiatkowska, M.; Krygier, K. 2006. Charakterystyka wybranych olejów tłoczonych na zimno, ŻYWNOŚĆ: nauka - technologia - jakość 13(2): 46-58. (in Polish).

Zdziennicka, A.; Szymczyk, K.; Jańczuk, B.; Longwic, R.; Sander, P. 2015. Adhesion of canola and diesel oils to some parts of diesel engine in the light of surface tension components and parameters of these substrates, International Journal of Adhesion and Adhesives 60: 23-30. https://doi.org/10.1016/j.ijadhadh.2015.03.001 